\title{
Corporate Governance - Emerging Economies Fraud and Fraud Prevention
}

\author{
Dr. Ponduri.S.B, Mrs. V. Sailaja, Mrs. Syeda Amina Begum \\ ${ }^{1}$ Head of the Department, ${ }^{2}$ Senior Assistant Professor ${ }^{3}$ Assistant Professor \\ ${ }^{1,2,3}$ Department of Management StudiesMahaveer Institute of Science and Technology (Affiliated to JNT \\ University, Hyderabad) Vyasapuri, Bandlaguda, Hyderaabd.500 005, India
}

\begin{abstract}
Just as it is impossible to know when a swimming fish will drink water, so it is impossible to find out when a corporate steward is stealing money"

From Kautilya'sArthashastra (300 B.C)

Cadbury (1992) defines corporate governance as the "whole system of controls both financial and otherwise by which a company is directed and controlled". In simple words it is all about promoting corporate fairness, transparency and accountability.

The opening of the economy has brought growth opportunities with improved competitiveness this has also given rise to cut throat competition in all sectors, which has tempted managers to adopt practices which at times dilute the ethical norms. This competition has put the onus on managers to show improvement in performances quarter by quarter persuading them to tamper with some of the best practices in the rat race for market share growth rate, visibility in securities market. The structure to ensure corporate governance includes the board of directors, top management, shareholders, creditors and all other stakeholders.

Frauds in corporate governance

According to KPMG fraud survey, organizations are reporting more experiences of fraud than prior years and are taking actions to deal with it. Seventy five percent of companies surveyed reports that they experienced increasing instances of fraud. While employee fraud is the most prevalent type of fraud experienced by organizations, financial reporting fraud and medical insurance fraud are the most costly. During the recent past the financial frauds are almost doubled. Organizations have taken reactive and preventive measures in controlling the corporate frauds like internal audit, internal controls, and notifications by an employee are the three ways of uncovering fraud.

The present paper is an exploratory study that focuses on various corporate frauds, genesis of the frauds, people responsible for various frauds and the role of regulatory bodies in overcoming those frauds. Key words: Stakeholders, Board of directors, KPMG fraud survey report, control, fraud, prevention.
\end{abstract}

\section{Introduction}

"Corporate governance is the system by which business corporations are directed and controlled. The corporate governance structure specifies the distribution of rights and responsibilities among different participants in the corporation, such as, the board, managers, shareholders and other stakeholders. It spells out the rules and procedures for making decisions on corporate affairs. By doing this, it also provides the structure through which the company objectives are set and the means of attaining those objectives a monitoring performance".

"The fundamental objective of corporate governance is the enhancement of long term shareholders value while, at the same time, protecting the interests of other stake holders"

Corporate Governance is not a new term; it is there since the inception of business houses as corporations itself. First it was started in the year 1970 in United States of America. It is needed to monitor the operations of a corporation. With the aim to avoid mismanagement it is becoming more and more vital for the survival of corporations. In spite of strict governance some corporations are still continuing doing frauds. In United States though they have a powerful system to prevent fraudulent activities still they have witnessed many frauds in capital markets, banking and financial sector frauds.

Hence US government initiated Sarbances-Oxly Act to regain the confidence of general public. Actually Enron, MCI \& Arthur Andersen's fall led the way to more fraud scandals. Now, corporate frauds are prevalent all over the globe, and hence India also became prey to this Spider's web. Recently we have seen Satyam scandal an accounting fraud by its own chairman Ramalinga Raju, Global Trust Bank scandal - a banking fraud, $2 \mathrm{G}$ scam -a telecommunication fraud, Coal \& Granite scam- an allocation fraud. Business scams are the most common forms of scam. Corporate governance has become the question of debate about its quality and prevention system in India. It raised the brows and doubts the quality of corporate governance in India. 
For the prevention of Frauds in United Kingdom Cadbury's Code started leading to many other codes. $\mathrm{CII}$ is one such code of corporate governance recommended Mr. Rahul Bajaj Committee. The codes will serve as a torch light to prevent frauds. In India we have Mr.Kumaramangalam Birla code under SEBI in 2001 after the collapse of WorldCom, Enron, and other corporate governance catastrophes. SEBI now decided to go for a second committee headed by Mr. Narayana Murthy from Infosys to maintain the balance between employee's economic and social goals.

\section{Fraud and Fraud prevention}

"Fraud is generally defined in the law as an intentional misrepresentation of material existing fact made by one person to another with knowledge of its falsity and for the purpose of inducing the other person to act and upon which the other person relies with resulting injury or damage. Fraud may also be made by an omission or purposeful failure to state material facts, which non-disclosure makes other statements misleading " World Bank report estimates that $60-80 \%$ of building projects (construction) in developing economies are undertaken without adequate permits and approvals which in itself is a big area of public fraud. Fraud is not limited to any one part of business it may happen at any part of business. The present research mainly focuses on various types of frauds such as banking, employees, technology, real estate, railway, accounting and auditing, telecommunication and others.

\section{Fraud Prevention}

According to Daniel Draz, By, M.S., CFE March 28, 2011 - CSO - improving internal controls is one of the most important tools in the corporate. Internal fraud controls aren't fire-and-forget. Smart collaboration and ongoing improvement will help keep fraud in check. Internal controls should not be thought of as "static." They are a dynamic and fluid set of tools which evolve over time as the business, technology and fraud environment changes in response to competition, industry practices, legislation, regulation and current economic conditions.

\section{Objectives and scope of the study}

The purpose of this paper is to analyze the relation between various types of frauds typologies and its prevention in maintaining good corporate governance systems. The research will empirically investigate, on a qualitative perspective, the major national and international scandals, chosen from different countries trying to get evidence about the relation between the corporate governance system of each firm, characteristics of different types of frauds and the remedies taken for various frauds, described with specific parameters.

$>$ To identify various types of corporate frauds in business.

$>$ To find the causes and people involved in various types of frauds.

$>$ To observe the possible remedies and suggest preventive mechanisms.

\section{Literature review}

The following paragraphs, after a brief review of the literature on various types of frauds and their relation with corporate governance is given on various categories of frauds, the methodology of the analysis and the empirical results is presented.Some of the articles reviewed are;

Dr.YKM Naidu and Mr.Ponduri Suresh Babu (2009) in Corporate Governance: Vision vs. Illusion $21^{\text {st }}$ march 2009 wrote that corporate governance is all about promoting corporate fairness, transparency, accountability and responsibility towards stake holders of the company corporate social responsibility.

Dr.G.Sailaja and Mrs.U.padmavathi (2009) despite plethora of rules and regulations enforced by both legal and regulatory authorities the compliance prescribed remain more on paper rather in real practice. Unless there is a change in heart and who need to implement the rules and regulations do so as a sacred national and international endeavors they owe to themselves and to the register and large. 2009, Page No: 50, Corporate Governance: Vision vs. Illusion.

Prof. V.Sekhar (2009) corporate governance would be good if the corporate focus on "delivery" rather mere on paper. Corporate governance will succeed if everybody feel their body feels their responsibility, PNo: 77, Corporate Governance: Vision vs. Illusion.

D. Sirisha discusses overview of the problems faced by Johnson \& Johnson's Tylenol Controversies. In 1982, it was found that some Tylenol capsules were laced with cyanide. This resulted in the death of many people. However, with the company's proactive and effective public relations program, Tylenol regained its market share within six months case from In the text book "Business Ethics and Corporate Governance "page no. 1734, Vol. 1, ISBN No. 81-7881-107-3. 
D. Sirisha once again faced problems when people died due to overdoses of Tylenol. Though the company received bad publicity and had to spend millions of dollars in legal settlements, J\&J was reluctant to have more explicit warnings on Tylenol's labels. This was in contrast to the company's response in the previous product tampering crisis. In the text book "Business Ethics and Corporate Governance", Vol. 1, ISBN No. 817881-107-3.

A.Mukund examines the controversy in the global fast food McDonald's was accused of wrongfully selling its French fries as $100 \%$ vegetarian products when they contained beef flavoring. It explores in detail the events that led to the controversy and the company's reactions to the allegations. It also discusses the eventual settlement of the lawsuit with the company paying damages to vegetarian groups and accepting that it had gone wrong. "Business Ethics and Corporate Governance", Vol. 1, ISBN No. 81-7881-107-3, case from page no. 3553.

Sanjib Dutta discusses an overview of the legal battle between Microsoft and Dept. of Justice (DOJ), U.S. in 1997, the sued Microsoft alleging that it forced computer manufacturers to ship its Internet Explorer Web Browser with its Windows 95 Operating System, the proceedings of the trial, which spanned more than three and a half years, various options before DOJ and the chances of Microsoft being sued by private companies in the future page no. 54- 68, "Business Ethics and Corporate Governance", Vol. 1, ISBN No. 817881-107-3,

Vivek Gupta in discusses the maltreatment of employees and sweatshop conditions in Nike's Asian Factories. In many Asian countries, Nike violated local labor laws. According to the Vietnam Labor Watch, Nike did not pay the minimum wages, did not provide proper working conditions, and did not take adequate health \& safety measures. In addition, Nike turned a blind eye to child labor and sexual harassment in its factories. Though the company has taken some measures to improve the situation, it has failed to improve the working conditions and put an end to the ill treatment of its employees, case from page no. 69- 83.

Dheeraj Misra and Sushma Vishnani (2012) in their research paper "Impact of Corporate Governance Regulation on Market Risk" attempts to analyze whether the corporate governance regulation has reduced the market risk of the Indian A-group companies of BSE. The results show that neither the corporate governance regulation imposed nor the amendments have been able to significantly reduce the market risk of A-Group companies of BSE. "Vikalpa - The Journal for Decision Makers", Vol. 37, Number 2, April - June2012, P No: 19-32.

Vivek Gupta in (2012) "Coke-ethical issues" discusses the crisis faced by Coke in Europe when people fell ill after consuming its products. The case also brings out the ethical dimensions involved in Coke's exclusive school contracts, which was done to promote soft drink sales among school children. In the text book "Business Ethics and Corporate Governance", ICFAI University Press, Vol. 1, ISBN No. 81-7881-107-3, P.No: $1-16$.

Dheeraj Misra and Sushma Vishnani (2012) "Impact of Corporate Governance Regulation on Market Risk" attempts to analyze whether the corporate governance regulation has reduced the market risk of the Indian A-group companies of BSE. The results show that neither the corporate governance regulation imposed nor the amendments have been able to significantly reduce the market risk of A-Group companies of BSE. "Vikalpa Journal for Decision Makers", Vol. 37, Number 2, April - June2012,page number 19-32, The

Vivek Gupta discusses the crisis faced by Coke in Europe when people fell ill after consuming its products. The case also brings out the ethical dimensions involved in Coke's exclusive school contracts, which was done to promote soft drink sales among school children. "Business Ethics and Corporate Governance", case from page no. 1- 16, Vol. 1, ISBN No. 81-7881-107-3.

\section{Major Areas of Fraud-Corporate Governance}

\section{$>$ Technology frauds}

Information Technology plays the dominant role in all types of frauds. It has so many advantages equal to that it also has certain limitations if it is used with a wrong intention. The accessibility of IT by the employees, trainers, system administrators, partners in the business and customers of course will increase the chances of occurrence of frauds and no security for the protection of confidential information like passwords, pin numbers, account numbers \& their details for banking and other transactions. With the advent of education IT has become a ball in the hands of fraudsters, they will throw and play with that as and when they like, in which ever manner and in whatever the direction. They are unauthorized to do so but they will do it with intention to gain some advantage for themselves in the form of money. To make the matter more worst it is very difficult to observe and catch the fraudster as said in the opening of this paper it is impossible to find that when a swimming fish will drink water. As it is said we cannot eliminate risk but we can minimize to some possible extent, in the same manner we cannot catch the fraudster immediately but we should be cautious and observe the things keenly to prevent any frauds in our corporations like missing documents, mismatch in names \& addresses, extra memos or overrated memos, wrong phone numbers or email ids, similar names \& addresses, general ledger out- 
of-balance, unauthorized use of the systems, prolonged working hours by an employee, unnecessary payments and many more.

\section{Fraud prevention}

With two measures of control we can minimize IT frauds.

1. Accessibility to Computer control which includes restricted persons by introducing biometric systems or unauthorized persons should not use the system, difficult passwords consisting of special characters and numerical to prevent hacking, close monitoring.

2. Accounting control internally which consists of posting of employees or transfer of employees and rigorous internal auditing through surprise visits and inspections, cross checking by employees itself, changing of computer passwords, reporting, and monitoring.

\section{$>$ Employee frauds}

Most fraud indicators are people-based and not technology based, although technology can be used to obscure evidence or cover up fraud behavior. According to the results of KPMG's fraud survey organizations are reporting more experiences of fraud in the recent past than in earlier years. $75 \%$ of company's survey reported they experienced increasing instances of fraud. Employee fraud is the most prevalent type of fraud experienced by many of the organizations. Another study of frauds in United States shows that auditors detected only $14.1 \%$ of the frauds, whereas employees detected $19.2 \%$, non-financial market regulators $16 \%$, media $16 \%$, analysts $14.7 \%$, strategic players $7.1 \%$, the Securities and Exchange Commission 5.8\%, Equity holders $3.2 \%$, professional service firms $2.6 \%$, and short-sellers $1.3 \%$. Out of all the types of frauds employee frauds are prominent and playing major role in corporate governance. The frauds like technology, banking, accounting, auditors, corruption, bribing all are related to people nothing but employees. Customers are the back bones of every organization.

Giving wrong or insufficient information to the customers also lead to corporate governance issues. Customers and all other stakeholders must be provided up to date information about the business so to as build confidence among the public and society.

\section{Preventive Mechanisms}

Stringent compliance programs, upgraded controls and regular monitoring could help to prevent corruption. Social control like building an ethical culture in the organization is one of the best ways to prevent any form of unethical practice including bribery and corruption. In order to curb corruption, organizations could adopt preventive mechanisms like comprehensive code of conduct and ensure strict enforcement of the code communicating zero tolerance towards corruption, structured whistle blowing mechanism to report potential bribery/ corruption issues, complete and periodic risk assessment mechanism including third party audits with specific reference to corruption related risks, regular monitoring mechanism to address issues arising out of bribery/ corruption. During the last two decades India has surged forward in its rank as an emerging economy. Creating awareness among the employees about dos' and don'ts in the organization. Developing ethical culture among the employees and organization. Attitudinal correction to correct the behavior of the employees will restrict the possibility of fraud.

\section{$>$ Banking fraud}

In a service industry like banking, corporate governance relates to the manner in which the business and affairs of individual banks are directed and managed by their board of directors and senior management. Frauds in the banking sector have seen a steady rise. The country's public sector banks have reported frauds amounting to nearly Rs. 9,000 crore to the Reserve Bank of India. This revelation came after questions were raised by the public regarding the quantum of scams in public sector banks. The country's largest PSU, State Bank of India tops the charts with frauds to the tune of Rs 1,221 crore. Bank of India has reported frauds amounting to Rs 709 crore, Canara Bank has revealed scams worth Rs 605 crore, IDBI Bank has indicated to RBI on frauds to the tune of Rs 609 crore. Central Bank has reported frauds amounting to Rs 562 crore. The entire list submitted in the public indicates that in the recent past, the amount involved in these frauds is a whopping Rs 8,848 crore and the cases registered are nearly 11,313. The central bank has taken several steps to sensitize banks and curb frauds in the banking space. There are several reasons for banking frauds like lack of properly trained and experienced employees in banks. There is a sudden and tremendous increase in banking business. This expansive explosion has created a vacuum of personnel. New recruiters often do not have adequate training or experience before they are put in responsible positions. Bank employees feel overburdened due to excess pressure. Dilution of policies and non-adherence procedures in banking system like unauthorized delegation at branches. Frauds in deposits accounts are mainly due to policy of "know your customer (KYC) is 
not followed properly. The Reserve Bank has issued several notifications sensitizing banks about common fraud prone areas. It has also issued caution notices against repeat offenders.

\section{Preventive Mechanism}

To develop the fraud protection policy and make it knowledgeable to all employees, customers, government, depositors and other stake holders. Superiors should closely monitor their subordinates and report immediately if any suspicion occurs. Internal monitoring will be of great help to deal with banking frauds. Credit limits must be set and strictly observed by the bank for employees as well as for the bad borrowers, lending and retrieving money or loan back policies should be made more stringent, job rotation and transfers must be implemented in banks for the benefit and overall development of banks and prevention of banks frauds as well.

\section{$>$ Accounting and financial frauds - Role of the accountants and auditors}

The role of accountants is very vital in corporate governance. Financial reporting is a crucial element necessary for the corporate governance system to function effectively. Accountants and auditors are the primary providers of information to capital market participants and other stakeholders. The directors of the company should be entitled to expect that management prepare the financial information in compliance with statutory and ethical obligations and rely on auditor's competence. The exercise of this choice is to improve apparent performance imposes extra information costs on users. In the extreme, it can involve non-disclosure of information. One area of concern is whether the accounting firm acts as both the independent auditor and management consultant to the firm they are auditing. This may result in a conflict of interest which places the integrity of financial reports in doubt due to client pressure to appease management. The satyam scandal and Enron collapse are an example of misleading financial reporting. Enron concealed huge losses by creating illusions that as third party was contractually obliged to pay the amount of any losses. However, the third party was an entity in which Enron had a substantial economic stake.Though investment norms are liberalized, India's Generally Accepted Accounting Practices (GAAP) and their educational syllabuses for accountants remain way behind when compared with the accounting standards in developed countries.

The role of auditors is very crucial for corporate governance. It is the heart and mind for fraud prevention.Auditors have the apex financial and accounting knowledge. Hence their importance is more in fraud detection and prevention. After post liberalization the role and importance of auditors have increased. Auditors must act freely and independently for proper results. Auditors must present in meetings should be made familiarize with the routines of corporations and must be provided with complete information. The role of Auditors is critical because they have to observe, monitor and detect the fraud that's why a free hand must be given to them for the smooth process of auditing.

Companies need to audit their final accounts at the end of every financial year. If it cannot be done there is every possibility to malpractice the past data. Outsides payments must be paid within the financial year so as to eliminate the possibility of unpaid expenses or unpaid debts. These are like payments to gratuity, provident funds, employee state insurance and others. Reconciliation of accounts should also be done in the same time.

\section{Preventive Mechanism}

As Auditors are independent of the corporation they act for the benefit of the shareholders and not for the companies. They must resort to internal audit first along with internal control. The attitude or approach of the employee towards auditors must be monitored by the companies for the smooth conduct of auditing and sharing of relevant information. An Auditor must ensure that corporate policies are the forefront for them along with the practices and procedures. They must be provided with in the time and correct information as and when they need. Companies need not trust their own auditor and make auditing by a statutory auditor so as to measure the checks and balances of accounts done by the company auditor. This is also called as external auditor to check the accounts done by the internal auditor. It is mandatory from the company's act 1956 every company must check its accounts by a statutory auditor before going ot submit the report $\mathrm{s}$ to companies' registrar. Even if any thing happened beyond the level of the statutory auditor companies adopt Forensic accounting to find the reasons for fraud and minimize the frauds in accounting practices by employees and accountants.

\section{> Real Estate fraud}

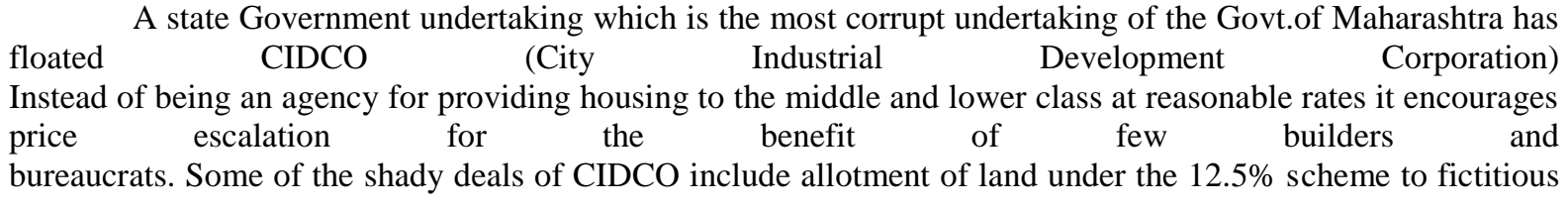


Companies. Change of reservation of plots for commercial use Systematic Destruction Of mangroves and reclaiming land and blatant violation of CRZ Rules.

\section{$>$ Railway Station Complex}

The station complex built by CIDCO at Mumbai the commercial areas was sold in the open market as carpet area (95-150) \% loading in 96-98 at much higher rates. In the year 2004 the same commercial premises were sold as carpet area $30 \%$ loading to friends and relatives and front men marketing department of CIDCO at a discounted price. Imagine built up area of two adjacent offices of same area are different.

\section{Telecommunication fraud - 2G SpectrumFrauds}

The second generation also called as $2 \mathrm{G}$. The 2 Gspectrum scam involved politicians and government officials in India illegally undercharging mobile telephony companies for frequency allocation licenses, which they would then use to create $2 \mathrm{G}$ subscriptions for cell phones. The shortfall between the money collected and the money which the law mandated to be collected is estimated to be 176,645 crore as valued by the Comptroller and Auditor General of India based on 3G and BWA spectrum auction prices in 2010. However, the exact loss is disputed.

\section{$>$ Coal allocation scam}

Coal allocation scam or Coalgate as referred by the media, is a political scandal concerning the Indian government's allocation of the nation's coal deposits to public sector entities and private companies. In a draft report issued in March 2012, the Comptroller and Auditor General of India (CAG) office accused the Government of India of allocating coal blocks in an inefficient manner during the period 2004-2009.

\section{Conclusion}

An ounce of prevention is worth a pound of investigation. The aim of this paper is necessarily simplifying a more complex reality, the various kinds' of corporate frauds and role of corporate governance. Corporate governance is a balanced development focuses on both wealth creation and social responsibility simultaneously. The essence of corporate governance lies in promoting and maintains integrity transparency and accountability in the highest echelons of management. Computer incidents occur in every organization. Management should pay special attention to those computer incidents where fraud is suspected and, in those cases, should take extra care in damage evaluation, collection of evidence and especially documentation of evidence collection and handling. One positive outcome of corporate scandals like Satyam, 2G Spectrum, Coal mines scam, real-estate scam was the sweeping reforms to corporate governance, which provided whistle blower protection to employees of public companies. Government should update the governing policies and see that every organization should strictly follow this rather put into paper alone. The accounting policies and procedures should update at par with global standards, auditors can be given complete independence in disclosing the financial data. Management should also immediately focus on tightening controls to remediate the weakness and perform periodic additional testing to verify the operating effectiveness of any new controls to prevent future occurrences. Much like quality in the 80's ethics and integrity have become business buzzwords. The management and leaders of business must internalize the values of ethical management as articulated by Norman Vincent Peale and Kenneth Blanchard.

\section{Acknowledgement}

This paper would not have been possible without the assistance and cooperation of number of people whom we would like to thank. We would like to express our sincere gratitude to Prof.YKM Naidu, Professor and Director PG studies, Pragathi Mahavidyalaya, Hyderabad, without whose timely guidance this paper would have remained complete.

We are very grateful to the management of our college where we have been working for and allowing us to do the course and project. We convey our special thanks to Dr..K.S.S.S.N Reddy, Principal, MIST, for rendering valuable support.

[1] CSV Murthy, "Entrepreneurship and Good Governance", $1^{\text {st }}$ edition, 2010, Himalaya publication, with ISBN No. 9789350244678 , pp. No. 161-226.

[2] Dheeraj Misra and Sushma Vishnani, "Impact of Corporate Governance Regulation on Market Risk", "Vikalpa-The journal for Decision Makers", April-June 2012, ISSN No. 02560909, Vol.37, No.2, pp. 19-32

[3] Alexander Dyck Adair Morse Luigi Zingales "who blows the whistle on corporate fraud"

[4] Corporate governance panel moots whistle Blower policy Business line DEC $16^{\text {th }} 2003$.

[5] "The India needs whistle blower Act" The Hindu march $25^{\text {th }} 2003$.

[6] "Vigilance for corporate governance growth" by C.B Smpathy, IPS

[7] ASCI Journal of Management - volume 27 -1998 Article by Shri. KRS Murthy, CorporateGovernance: A sociological perspective. 
[8] Aga, Anu R (2004) “Embracing CSR” forum for free enterprises, Mumbai.

[9] Piotr Mazukiewicz, 2008, "Corporate environmental Responsibility - Is a common CSR framework possible? -World Bank.

[10] Williamson O.E, Corporate Finance and Corporate Governance, Journal of Finance, 43, 78-83.

[11] Dr.YKM Naidu and Mr.Ponduri SB inCorporate Governance: Vision vs. Illusion 21 ${ }^{\text {st }}$ march 2009, Page No: 24, Corporate Governance: Vision vs. Illusion.

[12] Dr.G.Sailaja and Mrs.U.Padmavathi inCorporate Governance: Vision vs. Illusion 21 ${ }^{\text {st }}$ march 2009, Page No: 48, Corporate Governance: Vision vs. Illusion.

[13] Prof .V.Sekhar inCorporate Governance: Vision vs. Illusion $21^{\text {st }}$ march 2009, Page No: 50, Corporate Governance: Vision vs. Illusion.

[14] Organization for Economic Development (1999) OECD principles of Corporate Governance.

[15] Business Line and Economic times Newspapers, Jan\&March 2007-2008

[16] Incident response and fraud investigation - the role of the information technology auditor - By Willem Driven, Anthony Sameer, and David Taylor, Protiviti, Inc.

[17] Corporate Governance by John L. Colley, Jacqueline L. Doyle, Wallacw Stettinius. George Logan - Excel.

[18] Alexander DyckAdairMorseLuigiZingales "Who blows the whistle on corporate fraud".

[19] ASCI Journal of Management - Volume 27, 1998 - Article by Shri KRS Murthy: Corporate Governance: A Sociological Perspective.

[20] KPMG Fraud Survey 2003

[21] Vigilance for Corporate Growth", by Shri C.B. Satpathy,IPS.

[22] SuchetaDalal" Whistle blowing in banks: how can it be effective?

[23] http://www.scu.edu/ethics/practicing/focusareas/business/whistleblowing-update.html

[24] Laura Hartman, Abha Chatterjee. Perspectives in Business Ethics, McGraw Hill international.

[25] Rituparna Raj A Study in business ethics, HPH, Bangalore. 